\title{
THE LEGAL AND REGULATORY FRAMEWORK FOR SECURING OBLIGATIONS IN CREDIT GRANTING
}

\author{
Stanislav Syrovatkin \\ Ph.D., National Academy of Sciences of Ukraine, Ukraine \\ e-mail: stasian007@gmail.com,orcid.org/0000-0002-6905-0298
}

\section{Summary}

The aim of the article is to cover the theoretical aspects, legal and regulatory principles and development of ways to improve the legal and regulatory framework for securing obligations in the field of legal relations on credit granting. The study was conducted using the method of a systematic approach, which allowed to classify the views of the authors, to systematize the legal and regulatory framework, the method of unification, by application of which the proposals to address legislative shortcomings have been developed. The existence of problems in determining the legal status of objects of credit obligations of economic entities has been established. It is determined that in scientific works there is no universal approach to the composition and legal status of these objects, nor do they indicate the problems of current legislation in this field. It is revealed that the economic, civil legislation of Ukraine does not contain a complete definition of the composition of these securities. The problems of lack of legislative regulation of the problem of obligation and the procedure for assessing the state of the economic management, financial and economic condition, forecasting the risks of enforcement of loan obligations both from the loan providers subject to sponsors, guarantors and the latter in relation to borrowers, have been established. The availability of such problems in the field of normative and legal regulation in the USA, Poland and Ukraine has been proven, proposals for improving the provisions of the Ukrainian legislation in this area have been substantiated and formulated.

Keywords: loan providers, borrowers, enforcement of loan obligations, guarantees, securities.

\section{DOI: https://doi.org/10.23856/4427}

\section{Introduction}

The problem of protection of loan capital under conditions of the new global and national risks that affect the trustworthiness of borrowers requires the legislator to develop effective legal tools that would ensure compliance with obligations in the field of credit granting. Improvement of the legislative mechanisms for determining the security of credit obligations is becoming an urgent task and a condition for successful development of economic relations. The current state of legal regulation of this issue is not effective enough, that leads to a number of problems in credit relations, dispute resolution between economic entities at the judicial and prejudicial level. Lack of clear systematization of types, definition of regulation of the specified objects of credit legal relations is a peculiar problem both for domestic, and for foreign experience. In the view of the aforesaid, we believe that the study of this issue is currently topical, and emphasis of problems and ways to solve them in this field will increase the level of legal regulation. 


\section{Status and problems of normative legal regulation of securing obligations in the field of credit granting relations}

Issues of normative legal regulation of securing obligations in the sphere of legal relations on credit granting in separate directions are covered in the provisions of a scientific legal thought. In particular, in the scientific works of A. Moroz (Moroz, 2002:25), Yu. Moisieiev, Yu. Uralova (Moisieiev, Uralova, 2019: 174), O. Karasava (Karasava, 2015), S. Mirza, K. Kachalko Myrza, Kachalko, 2016) the guarantees, being a type of collateral for credit obligations, are considered, but availability of problems of normative legal regulation of their legal status and subtypes is not indicated. In the study of O. Hromova (Hromova, 2015) all possible types of these objects (guarantees, pledges, securities and penalties) are identified, but it is indicated that there are problems of legal regulation only in relation to penalties. Provisions of a scientific work of V. Kudriavtsev (Kudriavtsev, 2016) contain a classification of types of credit obligations, determined depending on the signs of securing (addressed) and the lack of legislative definition (not addressed), but the author does not indicate the problems of legal regulation of types, legal status of such objects. Although at the present stage there is a certain amount of scientific research, sources of case law and regulatory framework in this field, there is a necessity to identify a full range of problems and develop directions for their solution.

The content of the economic and civil legislation of Ukraine does not contain a clear composition, does not determine the legal status of securities for credit obligations of economic entities. Let's define the basic legal and regulatory principles established by the Ukrainian legislator in relation to this issue.

The provisions of the Commercial Code of Ukraine establish the following list of securities for credit obligations of economic entities, in particular: guarantees from solvent economic entities; sureties of other banks; security, property owned by borrowers; other types of securities (paragraph 2 of Article 346 of the Civil Code of Ukraine). It should be noted that the Civil Code of Ukraine does not allocate a complete list of securities for credit obligations of economic entities (between borrowers (economic entities) and loan providers (banking institutions and other economic entities). Namely, economic legislation emphasizes that a guarantee as a type of security for credit obligations can be provided only by banking institutions (paragraph 2 of Article 346 of the Civil Code of Ukraine), ie banks act as guarantors, and, accordingly, the object of credit relations is only a guarantee provided by such economic entities. Scholars studying the guarantee as an object of credit relations (A. Moroz (2002: 25), Yu. Moisieiev, Yu. Uralova (Moisieiev, Uralova, 2019: 174), O. Karasava (Karasava, 2015)) point to this provision of the legislation without subjecting it to discussion. The scientific works do not put forward views on the incomplete composition of the subjects of credit relations, that are the guarantors, and it is not stated that the composition of objects (types of guarantees) in this area is limited. Herewith, it is established in the paragraph 4 of Article 67 of the Civil Code that state-owned enterprises, including companies (excluding banking institutions), the authorized capital of which is fifty or more percent of shares (units or shares) owned by the state, and who perform the specified economic activity under the conditions of its coordination with the corresponding central authorities of the executive level can act as security or guarantors of credit obligations. It is important to note that another type of guarantee provided by the Commercial Code of Ukraine refers to those provided by the state-owned enterprises. In our opinion, this choice of the legislator is not clear enough, since the state form of ownership is not a sign of trustworthiness and ability to exercise the security of credit obligations. Accordingly, we state that the provisions of the commercial legislation of Ukraine on this issue are inconsistent. As evidenced by the content 
of civil law (paragraph 3 of Article 553 of the Civil Code of Ukraine), several or one person can act as guarantors. That is, within the Civil Code of Ukraine, the legislator does not set out a comprehensive definition of such entities, does not determine their legal status, but also does not impose restrictions on the form of ownership, types of economic activity. At the same time, the civil legislation contains a more complete composition of subjects, and, accordingly, the objects of guarantees, which are a part of the security of credit obligations of economic entities. Based on the provisions of the Civil Code of Ukraine, we state that the civil legislation of Ukraine stipulates that the guarantees of securities for credit obligations include all types of guarantees provided to persons with any legal status and form of ownership.

The provisions of the Civil Code of Ukraine contain a certain composition of security for fulfillment of obligations (Chapter 49), but do not specify those that may relate to the credit relations of economic entities. In view of the above, we believe that the main objects in this area at the general level are those provided by the Commercial Code of Ukraine, in particular, guarantees, sureties, pledges of property of borrowers, other types of guarantees. It should be noted that the civil law puts forward a certain composition of types of guarantees as a type of security for credit obligations. Namely, the provisions of the Civil Code of Ukraine (paragraph 1 of Article 560), compared to the Commercial Code of Ukraine, allocated an expanded composition of credit entities that can act as guarantors, including, in particular: banking institutions, insurance companies and other financial institutions. Therefore, civil law imposes certain restrictions on the legal status of guarantors, which is not defined in the content of the Commercial Code of Ukraine. Based on the subject composition submitted by the Civil Code of Ukraine, we determine that the types of guarantees that can act as collateral for credit obligations are as follow: guarantees provided by banking institutions; guarantees provided by insurance companies; guarantees provided by other financial institutions.

It is established that within the provisions of the Supreme Court of Ukraine set out in its Letter dated February 01, 2015 (Site LIGA.net, 2015), it is determined that any legal entities and individuals whose competences and property status will not raise doubts among load providers can act as guarantors. According to the research materials, this approach is followed by all banking institutions, courts and loan providers in the process of assessing the legal status of guarantors and warrantors. In view of the above, we assume that the supreme judicial body provides for the existence of sureties, guarantees provided by legal entities and individuals who have the required level of trustworthiness.

Consequently, we state that at the current stage of legislative security there is no clear and comprehensive composition of the security objects for fulfillment of credit obligations of economic entities. This affects different approaches to judicial and prejudicial settlement of commercial disputes in this area.

The study of legal regulation of this issue in foreign practice shows as follows.

The provisions of the US Commercial Code (Article 2509) contain the security objects for fulfillment of credit obligations of economic entities, these are, in particular, two types of guarantees. Namely: unsecured guarantees, which are accepted by loan providers under conditions of confidence in the financial stability of guarantors; secured guarantees, which are accepted by creditors in case the financial stability of the guarantor is doubtful, and are secured by the pledge of the guarantor's property. It should be noted that the US law provides for the possibility of maximum guarantee of credit obligations of economic entities at a level not exceeding 90\% of the loan amount. According to researchers (Flint, 2019; Semian, Taylor, 2019), in the regulation of credit guarantees in the United States of America there are problems associated with the fact that although the US legislature has identified these objects of credit obligations 
of economic entities, the requirements for assessment of trustworthiness of guarantors by loan providers and borrowers by both lenders and guarantors were not taken into account. Guarantors are assessed on the basis of reports and audit reports, assessment of borrowers is performed in a similar way. Accordingly, loan providers do not perform an independent assessment of guarantors and borrowers, this also applies to guarantors, who are guided by their reports and audit reports when concluding guarantee agreements with borrowers. Taking the above into account, the trends of recent years indicate that this approach of the legislator does not protect the loan providers, the borrowers face a crisis situation. We can mention the problem of the US legislation regarding determination of the need for mandatory financial monitoring of guarantors and borrowers before concluding credit agreements and contracts of guarantee.

The Polish legislation provides for the functioning of guarantees and securities as security objects for fulfillment of credit obligations of economic entities (Article 881 of the Civil Code of Poland (Tracz, 2019)). However, guarantees are the most common objects in this field, there is no use of guarantees at the level of different categories of credit operations. Article 881 of the Civil Code of Poland provides that the guarantors, unless otherwise provided by the agreement, act as joint subjects of legal relations for credit granting in Poland. It is determined that their liability as subjects of these legal relations is provided in the amount of the guarantee. A similar status of the stated participants is provided in the content of the Law of Poland "Banking Law". Via example of the analysis of one of the numerous lawsuits in this area, we identify the problems of lack of reference in the provisions of the Polish law not to the need for self-assessment by creditors of trustworthiness of borrowers with whom a contract of guarantee is concluded. As an example, the decision of the Court of Appeal of Krakow city dated March 6, 2019 No. I AGa 313/18 (Moment, 2019) in the case of a lawsuit by the loan provider (banking institution) to prosecute the guarantor related to the claim of the lender repayment of the latter as the entire amount of debt on the loan at interest on it, and the amount of penalties for late payment of credit debt by the borrower. It was revealed that the borrower was a network of pharmacies, which received a long-term loan from the bank on the basis of a guarantee, but six months later lost its trustworthiness and violated the bankruptcy procedure. During the first court appeal the loan provider could not prove that the guarantor should be liable for the principal debt, penalties for late payment of interest. Therefore, his second appeal to the Krakow Court of Appeal provided for a similar subject-matter of the legal claim. Based on the results of consideration of this case, the abovementioned judicial body resolved the following, in particular:

- that the liability of the guarantor (defendant) for this court appeal is equal to the amount of the guarantee, which is established both in the contract of guarantee and in the loan agreement. The amount of this guarantee is $80 \%$ of the principal debt of the loan;

- the person who is the guarantor (defendant) has assumed the specified amount of liability, and does not deny the coverage of debt on the loan in the amount of $80 \%$, while objecting to the payment of other $20 \%$ of the loan, interest on the loan, penalties for interest on the loan;

- oblige the guarantor (defendant) to pay the loan provider (banking institution) the specified amount of debt within 30 days as from the date of this court decision;

- the defendant party and the claimant party made significant mistakes in the process of assessing the trustworthiness of the borrower (Apteka Spółka z o.o. and K.). The defendant engaged an external audit (an audit company that constantly checked the financial and economic condition of the borrower), on the basis of the audit report, a decision to provide a guarantee was made. The loan provider did not conduct an independent assessment of the borrower's trustworthiness (Apteka Spółka z o.o. and K.) due to the fact that the guarantor submitted together with the contract of guarantee an audit report prepared by an independent audit 
company. Occurrence of crisis phenomena was not determined by the auditors six months prior, which calls into question the quality of such an assessment of trustworthiness;

- complaint of the claimant (banking institution) about bringing the defendant (guarantor) to legal responsibility regarding the payment of the full amount of the loan, interest and penalties for them is rejected.

Respectively, in addition to recognizing the guarantor's legal liability under the contract of guarantee and the loan agreement (the latter defines the same), this, in particular, is $80 \%$ of the loan arrears, rejected the claimant's claim to recover from the guarantor amounts not provided for in the contract provisions. The provisions of this judgment state that the loan provider, as well as the guarantor did not provide an effective assessment of the borrower's trustworthiness, which entailed financial losses for the guarantor, necessity to solve the problem of repaying another amount of debt (20\% loan amount, loan interest and interest penalties) for the loan provider by means of judicial procedure. It shall be noted that the issue of ineffective trustworthiness assessment is relevant for both Poland and Ukraine. Namely, there are many lawsuits related to claims to bring guarantors (securities) to repay debts under credit agreements, if the latter cannot be secured by borrowers due to loss of paying capacity. The content of court cases indicates the loss of trustworthiness and its insufficiently effective assessment at the stages of legal relations of concluding a contract of guarantee (or guarantees), credit agreements. Let's analyze the main directions and content of such court decisions in Ukraine, adopted after January 1, 2019, namely:

- Decision in case 904/1049/20 dated October 06, 2020, adopted by the Commercial Court of Dnipropetrovsk region, which considers the claim of the claimant (banking institution) to hold the guarantor (legal entity) liable on the debt obligations of the borrower (legal entity) due to violation of the last order of repayment of non-revolving loan facility, threat of loss of trustworthiness, lack of consent of the guarantor to pay all costs of the loan provider related to debt repayment (Rishennia u spravi No. 904/1049/20, 2020). Within the abovementioned court decision, the judicial body recognized the need for the guarantor to repay the full amount of the borrower's debt to the loan provider, as otherwise was not determined by the contract of guarantee, the loan agreement. Accordingly, the guarantor is responsible for liquidation of the debt of the borrower through his own approach to assessing the trustworthiness of the borrower;

- Decision in case 924/1288/19 dated April 14, 2020, adopted by the Commercial Court of Khmelnytskyi region, which provides for examination of the claimant's (banking institution) requirements for holding the guarantor liable for the debt obligations of the borrower (legal entity). This lawsuit took place due to the recent violation of the terms of liquidation of credit obligations, doubts from the loan provider on the trustworthiness of the borrower on the date of repayment of the loan, interest (Rishennia u spravi No. 924/1288/19, 2020). The judicial body made assumptions on insufficiently effective assessment of the borrower's trustworthiness by the guarantor and the loan provider (banking institution), and also made a decision to satisfy the borrower's claims in full. Therefore, the guarantor, due to the lack of reliable verification (only the assessment of the audit opinion submitted by the audit organization), suffered significant financial losses;

- Decision in case 908/1054/20 dated August 20, 2020, adopted by the Commercial Court of Zaporizhzhia region, which analyzed the claims of the claimant (banking institution) to hold the guarantor jointly with the borrower liable on the debt obligations of the latter. This lawsuit arose due to the violation by the borrower of the terms of liquidation of credit obligations, accrual of causes to assume by the loan provider that the borrower has reduced the level of trustworthiness (Rishennia u spravi No. 908/1054/20, 2020). The content of this 
court decision indicates the need for a thorough analysis by the guarantor of the borrower's trustworthiness, which was not carried out, and judging by the circumstances of the case, the decision on guarantee was made based on the results of independent analysis of financial statements. The claimant's complaint was approved, and a decision was rendered to satisfy the latter's claims in full by bringing the guarantor and the borrower to joint liability. Taking the above-mentioned into consideration, as well as in case of previous lawsuits, the guarantor suffered significant financial losses due to a correct assessment of the borrower's trustworthiness, respectively, these relationships were ineffective.

We can state that provisions of the legislation of Poland, the USA and Ukraine do not emphasize the necessity to assess the trustworthiness of the borrower by the guarantor, the loan provider, the conditions of such inspections, procedure and subjectivity of their payment are not defined.

\section{Ways to improve the legal and regulatory sphere in the area being studies}

In our opinion, the provisions of economic and civil legislation of Ukraine shall use a unified approach to determining the legal status of guarantors and warrantors. There is also a need to eliminate the indication in paragraph 4 of Article 67 of the Civil Code that state enterprises, including companies (excluding banking institutions), the authorized capital of which is fifty percent or more of shares (units or shares) owned by the state, and which provide such services subject to the approval of the relevant central executive authorities, can act as guarantors and warrantors of security for debt obligations of borrowers. This is due to the fact that this remark does not fully comply with the content of the Civil Code of Ukraine on the legal status of guarantors and warrantors on security for debt obligations of borrowers, differs from interpretation of the Supreme Court of Ukraine, all courts, banking institutions on the legal status of these persons. It should be assumed that argumentation of the Ukrainian legislation in the provisions of the Commercial Code of Ukraine on classification of warrantors, guarantors of state (semi-state) enterprises, the indication that they should not be banks, and the need to coordinate the provision of guarantees, warranties, in coordination with the central authorities, indicates a reference point for use the use of non-market methods of regulation, which are completely unjustified, differ from other laws and regulations.

In view of the aforesaid, we offer to change the content of paragraph 4 of Article 67 of the Civil Code of Ukraine and determine the legal status of the persons under study (guarantors and warrantors) as follows:

... Enterprises of various forms of ownership, entrepreneurs can perform raising debt funds (long-term and short-term), on contractual terms (for a fee) to act as warrantors, guarantors for security for debt obligations of borrowers in the case of proper trustworthiness, business reputation to provide services of this category. The procedure for providing guarantees, sureties from such persons provides for them to check the trustworthiness of borrowers to return credit to loan providers. The specified examination can be conducted both by internal forces of warrantors, guarantors, and by means of involvement of external audit. The cost of assessing trustworthiness is borne by borrowers who pay for its implementation before conclusion of contractual terms with warrantors, guarantors. If, based on the results of assessment, the latter do not make a decision on the provision of guarantees, sureties, the costs of trustworthiness assessment are not refunded to the borrowers.

This wording provides for the possibility of economic entities to raise loans, as it is the right of any enterprise, individual entrepreneurs and is defined in the text of the current legal 
act (paragraph 4 of Article 67 of the Commercial Code of Ukraine). This right has remained unchanged in the provisions of the Commercial Code of Ukraine, but the composition of persons who can use it has been expanded (enterprises of all forms of ownership, individual entrepreneurs have been added).

The emphasis in this definition is that both legal entities and natural persons-entrepreneurs can act as warrantors and guarantors, which results from the fact that the latter are also subjects of economic activity, and that such a possibility is provided by the legal position of the Supreme Court of Ukraine. (Letter to clarify this issue dated February 01, 2015 (Site LIGA.net, 2015)), the content of the provisions of the Civil Code of Ukraine on the legal status of guarantors (paragraph 3 of Article 553 of the Civil Code of Ukraine). In our opinion, the guarantors of security for debt obligations of borrowers can also be natural persons-entrepreneurs who have the appropriate level of trustworthiness, business reputation for provision of such services. It should be noted that the reference to the fact that the provision of guarantees, sureties is performed on contractual terms (for a fee) provides additional guarantee of loan reimbursement for loan providers, since free provision of such services may indicate the possibility of collusion of warrantors, guarantors and borrowers to obtain the loan funds. It should be noted that the provisions of the Commercial Code of Ukraine do not provide for the use of payment to warrantors, guarantors for their services, respectively, this can be interpreted as the possibility of provision of free services of this category and provision of paid services in this area (on contractual terms). But the latter is also, in our opinion, an additional guarantee for warrantors, guarantors in the event the borrowers cannot discharge their debts for this type of service. In particular, an economic dispute over compensation may be resolved in court, if the law provides for the payment of such services and the contract for the provision of guarantees specifies the amount of payment. It should be noted that we provide a systematic approach to the trustworthiness of borrowers before any contractual relations with warrantors, guarantors. This is aimed at protecting the financial interests of the latter, we also do not determine the possibility of being guided by the results of the assessment of the financial and economic condition of borrowers provided by them independently. Even if they submit audit reports provided by independent auditors on the date of receipt of sureties, guarantees, loans, warrantors and guarantors shall independently conduct an assessment of trustworthiness. At the same time, the reports of independent auditors can be the sources of such analysis, if they contain the necessary comprehensive information.

An important area of improving regulation in this area is the legislative consolidation of positions on obligation and procedure for assessing the state of the economy management, financial and economic condition, forecasting the risks of securing credit obligations by loan providers to warrantors, guarantors and on behalf of the latter regarding borrowers. Adherence to these procedures will eliminate the problems of non-performance of credit obligations for both loan providers and for security for fulfillment of credit obligations. Regarding the amendments to the Commercial Code of Ukraine, the following is offered: to set forth the provision of this legal document regarding the legal status of guarantees and loans, given in paragraph 2 of Article 346 of the Commercial Code of Ukraine taking into account the submitted offers. Namely:

In order to reduce the level of risk, the loan provider may provide loans to borrowers in case the latter provide the pledge of property, guarantees, sureties provided by any legal entities and individuals whose competences and property status will not be in doubt. To assess the trustworthiness, the loan providers shall assess the state of the economy management, financial and economic condition and forecast the risks of non-repayment of credit funds at a preliminary 
stage. Guarantees, sureties are provided by warrantors, guarantors on a fee basis after the establishment of the trustworthiness of borrowers, the cost of which shall be borne by the borrower.

\section{Conclusions}

The theoretical aspects, legal and regulatory principles and development of ways to improve the legal and regulatory framework for securing obligations in the field of legal relations on credit granting have been covered. The study of theoretical provisions, legal and regulatory framework has shown the availability of problems in determining the legal status of the objects of credit obligations of economic entities. It is determined that the scientific works do not contain a universal approach to composition and legal status of these objects, nor do they indicate the problems of current legislation in this field. According to the results of the analysis of the commercial and civil legislation of Ukraine, the existence of an incomplete definition of the composition of these securities was revealed, it was proved that this is due to gaps in determining the composition of the subjects of these securities. Taking into the account the stated range of problems, it is offered to eliminate the inconsistency of the legislation provisions at the level of the Civil Code of Ukraine and Commercial Code of Ukraine based on the content of the recommendations of the Supreme Court of Ukraine. Problems of lack of legislative regulation of the problem of obligation and the procedure for assessing the state of the economic management, financial and economic condition, forecasting the risks of enforcement of loan obligations both from the loan providers subject to warrantors, guarantors and the latter in relation to borrowers, have been established. The availability of such problems in the field of legal regulation in the USA, Poland and Ukraine has been proven. Considering the urgency of the issue, proposals for improving the provisions of the Ukrainian legislation in this area have been substantiated and formulated.

\section{References}

Flint R.E. (2019). Fraud, letters of credit, and the uniform Commercial code: it is time to untether the independence principle. Baylor Law Review, vol. 71, no. 2, pp. 351-418.

Hromova O.H. (2015). Do pytannia zabezpechennia vykonannia kredytnoho dohovoru. Postanovka naukovoi problemy [On the issue of ensuring the implementation of the loan agreement. Statement of a scientific problem]. Chasopys tsyvilistyky, vol. 18, pp. 60-64.

Karasava O.P. (2015). Poruka yak sposib zabezpechennia vykonannia kredytnykh zoboviazan: teoretychni ta praktychni aspekty [Bail as a way to ensure the fulfillment of credit obligations: theoretical and practical aspects]. Ekonomichna teoriia ta pravo, vol. 3(22), pp. 202-217.

Kudriavtsev V. (2016). Klasyfikatsiia sposobiv zabezpechennia vykonannia kredytnykh zoboviazan [Classification of ways to ensure the fulfillment of credit obligations]. Yurydychna Ukraina, vol. 9-10, pp. 21-27.

Moisieiev Yu.O., Uralova Yu.P. (2019). Deiaki pytannia dotrymannia i realizatsii pryntsypiv bankivskoho kredytuvannia subiektiv hospodariuvannia yak umova dlia vidnovlennia kredytuvannia $v$ Ukraini [Some issues of compliance and implementation of the principles of bank lending to businesses as a condition for the resumption of lending in Ukraine]. Yurydychnyi naukovyi elektronnyi zhurnal, vol. 6, pp. 172-176.

Moment powołania przesłanek egzoneracyjnych. Sad Apelacyjny w Krakowie. (2019). Retrieved from: https://sip.lex.pl/orzeczenia-i-pisma-urzedowe/orzeczenia-sadow/i-aga-313-18-odpowiedzialnosc-poreczyciela-moment-522878134 (accessed 26 April 2021). 
Moroz A.M. (2002). Bankivski operatsii [Banking operations]. Kyiv: KNEU. (in Ukrainian). Myrza S. S., Kachalko K.P. (2016). Tsyvilno-pravovi aspekty vidpovidalnosti poruchytelia [Civil law aspects of the guarantors liability]. Pivdennoukrainskyi pravnychyi chasopys, vol. 2, pp. 106-110.

Rishennia u spravi № 904/1049/20 (2020) Hospodarskyi sud Dnipropetrovskoi obl. [Decision in the case No. 904/1049/20 (2020) of the Commercial Court of Dnipropetrovsk region]. [United state register of court decisions]. Retrieved from https://reyestr.court.gov.ua/Review/92068318 (accessed 26 April 2021).

Rishennia u spravi № 908/1054/20 (2020) Hospodarskyi sud Zaporizkoi obl. [Decision in the case No. 908/1054/20 (2020) of the Commercial Court of Zaporizhia region]. [United state register of court decisions]. Retrieved from https://reyestr.court.gov.ua/Review/91240395 (accessed 26 April 2021).

Rishennia u spravi № 924/1288/19 (2020) Hospodarskyi sud Khmelnytskoi obl. [Decision in the case No. 924/1288/19 (2020) of the Commercial Court of Khmelnytsky Region]. [United state register of court decisions]. Retrieved from https://reyestr.court.gov.ua/Review/88749123 (accessed 26 April 2021).

Sait LIGA.net (2015). Analiz zastosuvannia sudamy zakonodavstva, yake rehuliuie poruku yak vyd zabezpechennia vykonannia zoboviazannia: vytiah z Lysta Verkhovnoho sudu Ukrainy vid 01.02.2015 r. Retrieved from http://search.ligazakon.ua/l_doc2.nsf/link1/VSS00093.html (accessed 26 April 2021).

Semian S., Taylor K.A. (2019). Lending and taking security in the United States: overview. Practicallaw. Retrieved from https://uk.practicallaw.thomsonreuters.com/9-501-871?transitionType $=$ Default\&contextData $=($ sc.Default $) \&$ firstPage $=$ true $($ accessed 26 April 2021).

Tracz G. (2019). Kredyt jako typ umowy [Loan as a type of contract]. Transformacje prawa prywatnego, vol. 4, pp. 81-138. 